\title{
Emerging Infectious Disease: Coronavirus Disease of 2019 (COVID- 19): What we know and what remains to be known?
}

\author{
Kuenzang Chhezom ${ }^{1}$
}

${ }^{I}$ Faculty of Postgraduate Medicine, Khesar Gyalpo University of Medical Sciences of Bhutan, Thimphu, Bhutan

In December 2019, cases of Pneumonia of unknown cause was reported in Wuhan City, Hubei Province, China caused by SARSCoV-2 of Coronaviridae family ${ }^{1}$.

The COVID-19 outbreak is the third documented spillover of an animal coronavirus to humans in only two decades that has resulted in a major epidemic syndrome that is potentially fatal ${ }^{2}$. Initially when the disease outbreak happened it was linked to the Huanan South China Seafood Market, a live animal or 'wet' market, suggesting a zoonotic origin of the virus ${ }^{3}$.

The incubation period of COVID-19 ranges from 2 to 14 days and $97.5 \%$ develops symptoms in 11.5 days $^{4,5}$. Studies have shown that people aged 60 years or older and people with underlying chronic diseases like chronic respiratory diseases, cardiovascular diseases, severe obesity, diabetes, renal diseases, liver disease have higher risk of getting infected with high fatality rates $^{6}$. Transmission among human beings occur via close contact with infected person, through respiratory droplets or via fomites. Though airborne transmission is not reported, it is possible in the clinical settings during aerosol generating procedures ${ }^{7}$. The virus has been detected in blood, cerebrospinal fluid, urine, saliva, tears, and conjunctival secretions. Patients with diarrhea are more likely to have viral RNA in their stool ${ }^{8}$. Nosocomial transmission in healthcare workers and patients has been reported ${ }^{9}$.

Studies suggest that some people can be contagious during the incubation period (Presymptomatic transmission) ${ }^{10}$ and also can be asymptomatic carriers ${ }^{11}$, and children play an important role in community spread ${ }^{12}$. Multiple superspreading events have been reported and super spreaders can pass the infection on to large numbers of contacts, including healthcare workers ${ }^{13}$. Regarding intrauterine infection some retrospective studies have shown that there is no evidence but vertical transmission could not be ruled out since virus specific antibodies were detected in neonates born to COVID -19 mothers ${ }^{14}$.

A patient of COVID-19 manifests symptoms that is suggestive of a respiratory infection with a symptom severity ranging from a mild common cold-like illness, to a severe viral pneumonia leading to acute respiratory distress. Some patients also presented with gastrointestinal symptoms and the most

Corresponding author:

Kuenzang Chhezom

kuenzangchhenzom@kgumsb.edu.bt recent being anosmia.

From the lessons learnt during outbreaks like Ebola, SARS, MERS, WHO accelerated its R\& D blueprint for developments in diagnostics, treatments and vaccines ${ }^{15}$.

Following diagnostic tests can be used in COVID-19 depending on the severity of illness ${ }^{16}$.

1. Real-time reverse transcriptase Polymerase Chain Reaction

2. Chest X-ray

3. Computed Tomograph (CT) Chest

4. Serology

5. Lung ultrasound

Various treatments and vaccines are trialled in the treatment of COVID-19 but no treatments have been approved or shown to be safe and effective. However, there are several treatments being used off-label. ${ }^{17}$

Globally vaccine R \& D has initiated development of vaccine candidates for COVI-19 which are in different phases of clinical trial and is expected to be available for emergency use or for similar protocol by early $2021^{18}$. According to WHO, there is no evidence of BCG vaccine being protective against COVID-19 but clinical trials are underway.

In conclusion, with this continuing pandemic, many things regarding the SARS-COV-2 infection still remains to be explored and confirmed including the reservoir and the intermediate host, symptoms, the possibility of airborne transmission, effects of weather, mother to child transmission, vaccines and treatment among many others.

\section{REFERENCES}

1. Ren LL, Wang YM, Wu ZQ, Xiang ZC, Guo L, Xu T, et al. Identification of a novel coronavirus causing severe pneumonia in human: a descriptive study. Chin Med J (Engl). 2020; 133(9): 1015-1024. [PubMed | Full Text | DOI]

2. Gorbalenya AE, Baker SC, Baric RS, de Groot RJ, Drosten $\mathrm{C}$, Anastasia G, et al. The species severe acute respiratory syndrome- related coronavirus: classifying 2019-nCov and naming it SARS-CoV-2. Nat Microbiol 2020; 5:536-44. [Full Text | DOI] 
3. Li Q, Guan X, Wu P, Wang X, Zhou L, Tong Y, et al. Early transmission dynamics in Wuhan, China, of novel coronavirus-infected pneumonia. N Engl J Med. 2020; 382(13):1199-207. [Full Text | DOI]

4. Centers for Disease Control and Prevention. Coronavirus disease 2019(COVID-19): symptoms of coronavirus.2020. [Full Text]

5. Lauer SA, Grantz KH, Bi Q, Jones FK, Zheng Q, Meredith HR, et al. The incubation period of coronavirus disease 2019 (covid-19) from publicly reported confirmed cases: estimation and application. Ann Intern Med. 2020. [Full Text | DOI]

6. Zhang J, Wang X, Jia X, Li J, Hu K, Chen G, et al. Risk factors for disease severity, unimprovement, and mortality of COVID-19 patients in Wuhan, China. Clin Microbiol Infec. 2020 Apr 15. [Full Text | DOI]

7. Chan JF, Yuan S, Kok KH, To KK, Chu H, Yang J, et al. A familial cluster of pneumonia associated with the 2019 novel coronavirus indicating person-to-person transmission: a study of a family cluster. The Lancet. 2020 Feb 15;395(10223):514-23. [Full Text | DOI]

8. Wei XS, Wang X, Niu YR, Ye LL, Peng WB, Wang ZH, et al. Diarrhea is associated with prolonged symptoms and viral carriage in COVID-19. Clin Gastroenterol Hepatol. 2020. [Full Text | DOI]

9. Wang D, Hu B, Hu C, Zhu F, Liu X, Zhang J, et al. Clinical characteristics of 138 hospitalized patients with 2019 novel coronavirus-infected pneumonia in Wuhan, China. JAMA. 2020;323(11):1061-9. [Full Text | DOI]

10. Wei WE, Li Z, Chiew CJ, Yong SE, Toh MP, Lee VJ, et al. Presymptomatic transmission of SARS-CoV-2 - Singapore, 2020 January 23-March 16. MMWR Morb Mortal Wkly Rep. 2020 Apr 10;69(14):411. [PubMed | Full Text | DOI]
11. Kimball A, Hatfield KM, Arons M, James A, Taylor J, Spicer $\mathrm{K}$, et al. Asymptomatic and presymptomatic SARS-CoV-2 infections in residents of a long-term care skilled nursing facility-King County, Washington, March 2020. MMWR. Morb Mortal Wkly Rep. 2020;69. [PubMed | Full Text | DOI]

12. Qiu H, Wu J, Hong L, Luo Y, Song Q, Chen D, et al. Clinical and epidemiological features of 36 children with coronavirus disease 2019 (COVID-19) in Zhejiang, China: an observational cohort study. The Lancet Infect Dis. 2020. [Full Text $\mid$ DOI]

13. Stein RA. Super-spreaders in infectious disease. Int J Infect Dis. 2011 Aug;15(8):e510-3. [Full Text | DOI]

14. Alzamora MC, Paredes T, Caceres D, Webb CM, Valdez LM, Rosa ML, et al. Severe COVID-19 during pregnancy and possible vertical transmission. Am J Perinatol. 2020 Apr 18. [PubMed | Full Text | DOI]

15. World Health Organization. R \& D blueprint and COVID-19. Geneva. Switzerland. World Health Organization;2020. [Full Text]

16. BMJ best practice. Coronavirus Disease 2019 (COVID-19). BMJ 2020 May15; 140. [Full Text]

17. Sanders JM, Monogue ML, Jodlowski TZ, Cutrell JB. Pharmacologic treatments for coronavirus disease 2019 (COVID-19): a review. JAMA. 2020. [Full Text | DOI]

18. Le TT, Andreadakis Z, Kumar A, Roman RG, Tollefsen S, Saville M, et al. The COVID-19 vaccine development landscape. Nat Rev Drug Discov. 2020 Apr 9;19:305-6. [Full Text] 